\title{
Historical earthquakes in Mexico. Past efforts and new multidisciplinary achievements
}

\author{
Virginia García Acosta \\ Centro de Investigaciones y Estudios Superiores en Antropología Social (CIESAS), Mexico D.F., Mexico
}

\begin{abstract}
The 1985 Mexican earthquakes demonstrated that knowledge concerning their history was still scarce and precarious. In fact those earthquakes acted as triggers, because it was then when a new field of research began to develop: disaster historical research. An initial task was to retrieve the history of earthquakes in Mexico in order throughout to produce an exhaustive inventory. The main result was a paradigmatic catalogue, published some years ago as the book Los sismos en la historia de México (Earthquakes in Mexican History). It contains information about every event along 450 years of Mexican seismological history. This paper will focus on the background of this seismological compilation and its characteristics, addressing mainly methodological items concerning sources, qualitative and/or quantitative data, the importance of joint and multidisciplinary efforts, and the research they have inspired on historical earthquakes investigation in Mexico.
\end{abstract}

Key words earthquakes - Mexico - catalogues seismological compilations - pictograms

\section{Introduction}

The Mexican Republic is located in a highly seismic region of the planet, mainly because the Cocos and the Rivera plates subduct below the North American plate, and the Pacific plate separates from the North American plate along the Baja California Gulf spreading center. Besides, the country is crossed by the Trans-Mexican Volcanic Belt, part of the Pacific Ring of Fire. Numerous earthquakes have occurred throughout Mexican history (fig. 1). One of the earthquakes with the greatest magnitude has been the one that occurred

Mailing address: Dr. Virginia García Acosta, Centro de Investigaciones y Estudios Superiores en Antropología Social (CIESAS), Juárez 87, Tlalpan, CP 14000, México D.F., Mexico; e-mail: vgarciaa@juarez.ciesas.edu.mx on 19 September 1985. That year constituted a breaking point in Mexican seismological history in more than one sense. In fact, catalogue production has to be understood before and after 1985. A definitive interest in rescuing Mexican seismological history with a holistic perspective has acquired special importance since then.

Up to 1985 there existed two types of seismological catalogues or compilations:

a) parametrical ones produced with an exclusive interest for seismologists, corresponding mainly to the instrumental period of Mexican seismology and, as such, covering basically the 20th century;

b) earthquake compilations produced mainly during the 19th century, as part of the greatest amount of enlightenment production linked to the growing interest in understanding and explaining Nature.

Since 1985 a joint interest developed among historians, anthropologists, ethnohistorians and seismologists to construct a reliable and multidisciplinary catalogue. Our task started having a gen- 


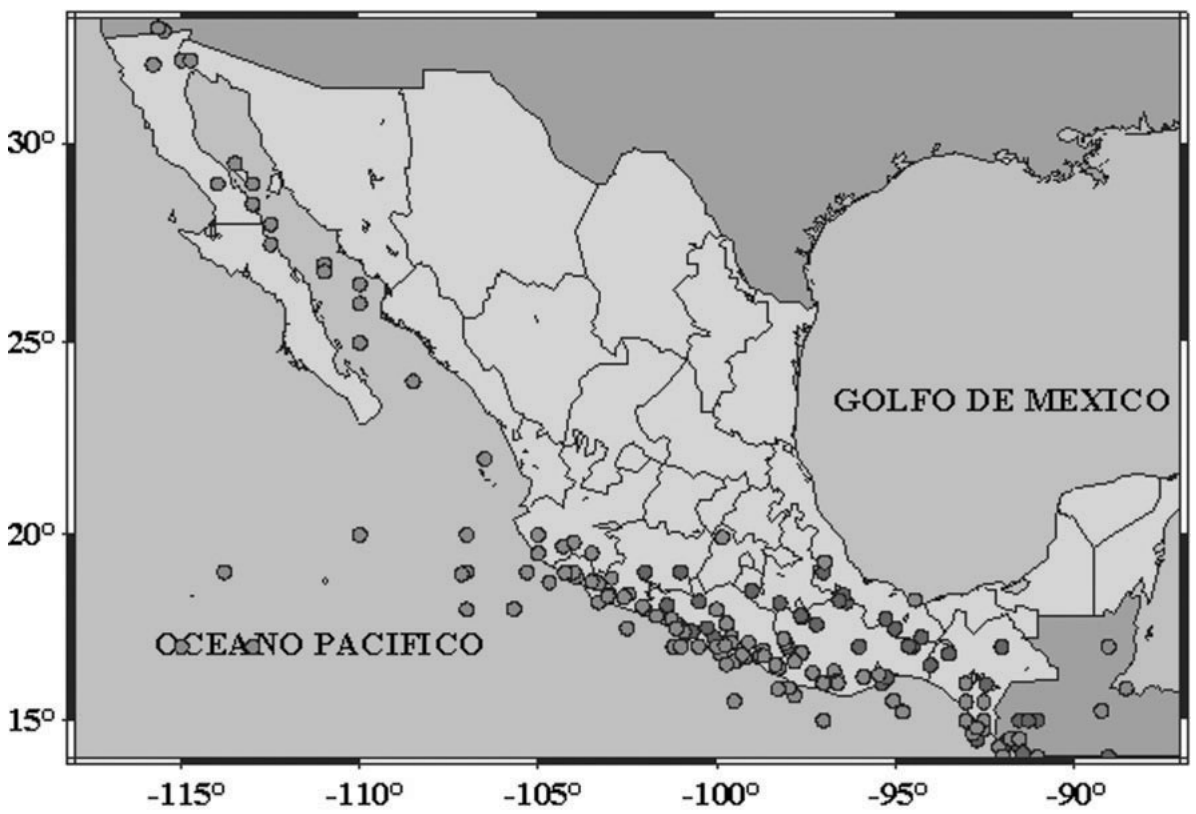

Fig. 1. 20th century Mexican earthquakes with $M \geq 6.5$ (courtesy of Servicio Sismologico Nacional, Instituto de Geofisica, UNAM, Mexico).

eral knowledge on catalogues or compilations from other countries (China, the Caribbean, Japan) and particularly, the magnificent 19th century work of the French Count Montessus de Ballore on the seismological history of the Andes. For Mexico there existed some 19th century compilations which had omissions and lack of precision, but in fact they were the starting point.

A short time later, in 1987, the joint effort yielded its first product with the edition of the book «Y volvió a temblar», which means «And it trembled again» (Rojas-Rabiela, et al., 1987). This title reminds us of the first sentence of many colonial documents that reported earthquake occurrence. One year later, in 1988, the second great product appeared (García-Acosta et al., 1988). Research continued for several years, during almost one decade. In 1996 the most recent effort appeared with the edition of «Los sismos en la historia de México» («Earthquakes in Mexican History»), which covers more than 450 years of Mexican seismological history, from 1455 up to 1913 (García-Acosta and Suárez-Reynoso, 1996).

\section{Methodology}

Historical earthquake research was virtually a new field in Mexico. As such, we did not have a guide or an accurate indication to know what path we should follow. For this reason, the methodology of this work was developed step by step.

Some methodological paths we followed in this retrieval of the seismological history of Mexico will be mentioned below: a path we may baptize as methodological lessons learnt.

\subsection{Multidisciplinary team}

One of the main methodological elements was working in a team, as a team, with a team. 
This is absolutely necessary in studies that, like this one, wish to be exhaustive.

\subsection{Bibliographical sources}

To guide the search in libraries, we used a series of published bibliographies, some of them even coming from 19th century, and we also used published indexes, mainly to guide our search in archives that were really useful before leaving Mexico on our way to the Archivo General de Indias located at Seville in Spain.

\subsection{Temporal frame}

Source availability determined the temporal frame. As such, the oldest date goes as far as the 15 th century, while the most recent date was 1912. This period corresponds to what is called the non-instrumental era of Mexican seismology, because the instrumental era began in 1910 when the National Seismological Network was set up. Thus, our compilation ended in 1912 because in this year there occurred an earthquake with specific characteristics and important effects in Mexico City, for which it was particularly interesting to compare the new quantitative data coming out from the instruments with the qualitative one.

\subsection{Spatial frame}

Next, we had to define spatial limits. Besides covering Mexico City, and the Valley of Mexico in which Mexico City is located, the spatial limits were defined with the seismologists choosing the 10 Mexican states (estados in Spanish) that had two characteristics: they have been historically identified by their great seismic activity and, offered archives, libraries and depositories which could be explored and used.

The ten Mexican states that were chosen were, from north to south the following: Nayarit, Jalisco, Colima, Michoacán, Veracruz, Estado de México, Puebla, Guerrero, Oaxaca and Chiapas.

\subsection{Critical route}

What we called a «critical route» or work route had to be defined, mainly to know when to continue and when to stop. I will mention two examples of what we did with journals and archives.

The large number of 19th century Mexican journals that exist in journalistic depositories imposed certain modifications to the task method we had employed with bibliographical sources. The criterion had to be more selective, and the route had to be more specific. At the beginning we tried to find out the most important earthquakes, and went through the journals for the following 30 days, reviewing different newspapers at diverse dates. But this route had to be changed because the information related to a certain quake varied from one newspaper to another. The variation was not only in quantitative terms but also in qualitative ones. We then had to choose the «Little Red Riding Hood long way» and decided to examine simultaneously several newspapers for the same date.

Once we had finished with the search for strong and important earthquakes, and having identified important gaps, we made a daily systematic review of the newspapers to fill the gaps. This path led us to find out some great earthquakes not previously identified as such, and now well documented in our compilation with journalistic information. That is the case of the event known as «Earthquake of All Saint's Day» which occurred on Mexico's Saint's Day, 2 November 1894.

The second example comes from the archives, and specifically from the Archivo General de Indias, located so far away from Mexico and where the research time had to be optimized. We chose four criteria:

i) to look through all the legajos or sections where we knew there were useful data on earthquakes, as those including documents asking for tax-exemption;

ii) to fill the gaps we already had, that is to search specifically for the years for which we had no data (this criterion proved useless and took up too much of our valuable time);

iii) to search for specific dates of specific earthquakes we wanted to document in detail (this criterion was also discouraging; the «un- 
grateful search» began to threaten the research);

iv) previous experiences in Mexican archives led us to look for documents with certain characteristics that gave us wonderful results related to building reconstruction and, as such, probably related with earthquake occurrence. We placed special emphasis on documents coming from sections called propios and reales novenos (GarcíaAcosta and Suárez-Reynoso, 1996). This one was a more fruitful choice in several senses.

We just mentioned «ungrateful» or «useless search». As usual, we had to face it. It represents what our Italian colleagues call «negative sources»(Gazzini, et al., 1991). One extreme example comes from Emilio del Castillo Negrete's masterpiece «México en el siglo XIX» («Mexico in 19th century»). Only in one of its 29 volumes did we find useful data.

As the useless research in bibliographical sources grew, we abandoned them and went to journals, when this one grew, we jumped to archives, and so on. Sometimes an ungrateful search is continuous and discouraging. That is why we decided to help other professionals who adopted this technique, and tell them explicitly where and what not to look for (GarcíaAcosta and Suárez-Reynoso, 1996).

\section{Sources}

According to their contents, sources can be divided into primary and secondary. According to their origin, sources are archives, bibliographical, old newspapers and iconographic. Let us take a brief look at these main sources.

\subsection{Archives}

Undoubtedly, the main source of information for historians are the archives. They require a considerable investment of time, and the participation of experienced professionals in archive work, in paleography, and in other specialities such as pictographic writing, as we will see later.

These depositories lack specific sections to look at. Among all the archives we visited, only two of them in Mexico had specific sections dealing with earthquakes: the Historical Archives of Jalisco, with a section named «natural phenomena», and the Diocesan Archives at San Cristóbal de las Casas, Chiapas, with a file dealing with earthquakes and volcanic eruptions in the section Asuntos Civiles-Asuntos Regionales (Civil Affairs-Regional Affairs).

We worked in private and public archives. The latter are organized in Mexico at different levels, according to the political-administrative division of the country, so they can be municipal, state or federal archives. Finally, we had a splendid opportunity to search in the Archivo General de Indias in Seville (Spain), looking for data from Colonial Mexico that were not found in Mexican depositories. Other colleagues gave us information coming from other archives, such as data from the southern Mexican border coming from the General Archives of Central America.

Archives and codices were the sources that provided the earliest data about historical earthquakes.

\subsection{Bibliographical sources}

200 bibliographical sources provided primary as well as secondary data for the catalogue, going from codices written in pictographic characters, to 20th century published books, passing through 19th century manuscripts.

A good example came from codices, the pictographic documents where Mesoamerican people recorded the most important events of their daily life. They are called «painted books» because the writing system used is pictographic, in which each element is determinant: shape, size, color, position of every glyph. The recording of earthquakes, combining written and calendar systems, was especially important because of Mesoamerican cosmovision. Earthquakes were recorded combining the earth and movement glyphs (Fuentes, 1987). As such the earthquake pictogram is the result of the association of both glyphs (fig. 2). Next to the earthquake pictogram there always appears a chronological glyph showing the date of the event, that is to say the date when the earthquake or any other natural, social or political phenomenon occurred 


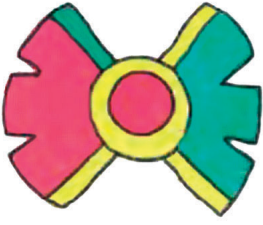

Ollin

Movimento

Movement

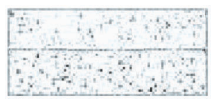

Tlalli

Tierra

Earth
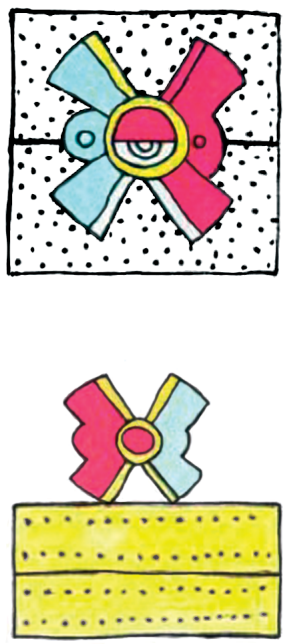

Fig. 2. Earth and Movement (Tlalli and Ollin in Nahuatl Language) glyphs and their combination meaning Earthquake (Tlalollin).

(fig. 3). Codices offer scattered information, but in some cases it is the only one we have for the Pre-Hispanic period.

Manuscripts are other important bibliographical sources, like the one written by Martínez Gracida (1890), found in the General Archives of Oaxaca, which includes nationwide as well as world-wide information on earthquake occurrence from 1507 to 1885 .

\subsection{Old newspapers}

In our research we used 36 newspapers, half of them printed in Mexico City and the other half outside the capital, mainly in the state capitals. Most were printed during the nineteenth Century, when Mexican journalism was established. Early Mexican newspapers were associated with the initial development of printing in New Spain, between 1536 and 1540. The first forms of printed information were called hojas volantes or papeles sueltos (flyers or «loose sheets»). The first flyer that appeared in Mexico City, printed by the Italian Juan Pablos (considered the first printer in Mexico), was a description of the earthquake felt during the night of 10-11 September 1541. It was signed by the notary Juan Rodríguez as a witness.

Research in old newspapers and in archives requires the greatest amount of time. We had to go through the newspapers on a daily, monthly

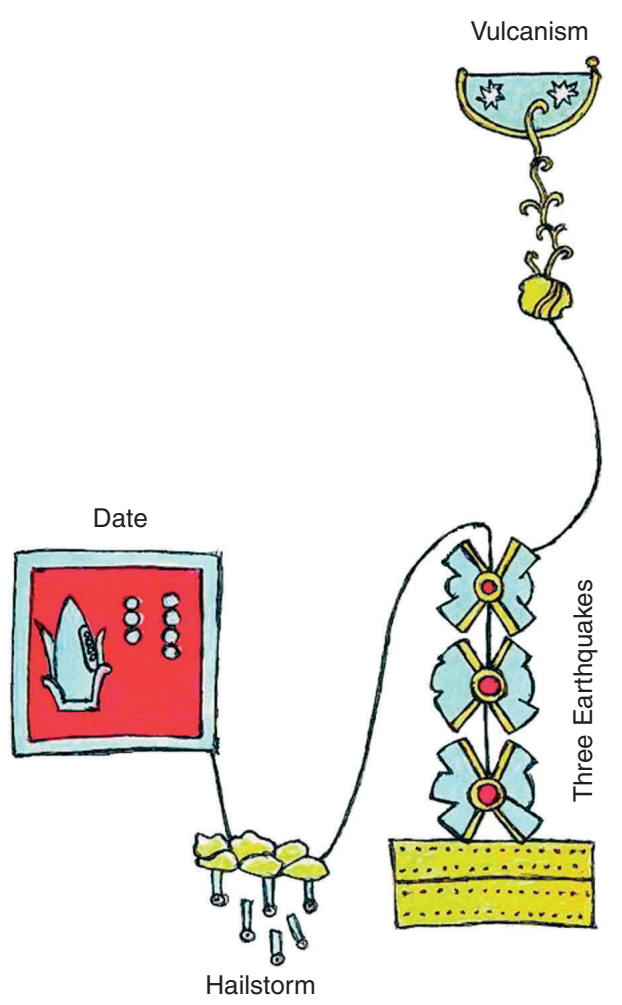

Fig. 3. Pictograms coming from Pre-Columbian or Early Post-Conquest Codices. 
and yearly basis to find out a few pieces of information. First we went through the few colonial newspapers, then the 19th Century and early 20th Century, which definitely yielded more information. Data from newspapers cover a period of almost 200 years $(1722,1728$ to 1742 and 1784 to 1912 ).

\subsection{Iconographical sources}

Iconographic sources were not explored or used enough in our research on Mexican earthquakes. They represent an enormous field to look at, and were used more exhaustively in our last research dealing with what we call agricultural disasters in Mexican History, that is droughts, floods, heavy rains, and so forth (García-Acosta et al., 2003; Escobar, 2003).

We used ex votos or retablos for the covers of the two volumes of «Earthquakes in Mexican History». These retablos are «an old and deepseated expression of Mexican popular religiosity» (Rodríguez-Lapuente, 1995), and they are frequently associated with disasters.

Primary information used in the compilation came from archives, newspapers and over $60 \%$ from bibliographical sources. The Introductory chapter to the book «Earthquakes in Mexican History» contains a detailed analysis of each source for the reader to understand its characteristics and the type of information it provides. This source analysis led to the following four criteria: i) type of source; ii) type of material; iii) how the material is presented; iv) reliability and deficiencies.

Newspapers provided the bulk of earthquake information, especially for the 19th century. However, in an excellent article on the use of information taken from British newspapers, Musson found that one of their main deficiencies is that the information was not treated with scientific interest, so it might be incomplete; it often happens that they do not always describe or even mention some earthquakes found in other sources. Hence the recommendation is to use, as we did, as many different newspapers as possible (Musson, 1986). So, even when journalistic information is considered primary (ex- cept when it deals with prior events), it has to be compared with information coming from other sources in order to determine its accuracy and reliability.

The details on how the information was extracted, ordered and systematized appear in the Introduction to «Earthquakes in Mexican History». The required characteristics of any pre-instrumental earthquake compilation or, given the case, any historical long-term catalogue are four: i) homogeneity; ii) continuity; iii) complementarity; iv) reliability.

Those four requirements have to be accomplished with sources, include textual information, as well as all the information obtained in the documents.

By combining several sources in a complementary way, we managed to cover almost all our study period. This proves the usefulness of this method not only in this type of long-period research, but in any exhaustive study. Comparing several sources also helps us to solve dating problems, such as counting a single earthquake twice, mistaking an earthquake for its aftershock or its foreshock, confusing two different earthquakes, and so forth. It also solves toponymic problems, such as the town names in indigenous languages, towns that changed names, and so forth. Thus, complementing and comparing different sources really matters.

Only in this way will the reader, user, and researcher be able to use the information, to have confidence, and to choose or discriminate it for his research purposes. They are the minimal requirements for this type of research that has a multidisciplinary origin and objectives. It is so because potential users are not only specialists in earth sciences and engineering, but also historians, ethnohistorians, anthropologists, sociologists, art historians, architects, urbanists and stakeholders in general whose work and decisions are related to these issues. For example, diverse earthquake-related studies developed by historians, ethnohistorians and anthropologists have increased during recent years. An example of this are the contents of the second volume of «Earthquakes in Mexican History» (García-Acosta, 2001) that include analysis on topics like: the evolution of 
seismic records throughout centuries; scientific thoughts about the origin of earthquakes; historical social responses to earthquake occurrence throughout Mexican History.

\section{Catalogues and seismological compilations before and after 1985}

Catalogues and seismological compilations include primary and secondary material. The first ones were developed in the 19th century mainly by engineers, geologists, meteorologists and several members of scientific societies (table I). Many of those coming from the 19th century have serious mistakes and omissions. For this reason, they have to be checked and compared with original data. That is, they do not have the homogeneity, continuity, complementarity and reliability required for these sources. The same happens with the work of Juan Orozco y Berra (1887-1888) «Efemérides seísmicas mexicanas» («Mexican Seismic Ephemeris»), which until recently was the only reference for specialists, although it contains imprecisions, dating errors and omissions.

This interest to maintain the historical memory of earthquakes was reborn in Mexico after the 1985 earthquake, a breaking point in this type of research as I mentioned before. After that event, many local compilations were made especially for Mexico City ( $c f$. Amerlinck, 1986; González-Polo, 1985 and Manzanilla,
1985). There have also been many regional, state or local efforts, such as the work of Juan Vizcaíno (1986) who studied the seismic history of his native town Zapotlán or Ciudad Guzmán in Jalisco, a city damaged by many earthquakes including the 1985 one. It is also the case of César Luna Bauza (1992), who studied the whole state of Veracruz. Each one covers different periods: 1543-1985 for Zapotlán and 1900-1994 for Veracruz. An even greater work was the catalogue of Garduño et al. (1998) which covers a large western region including three Mexican states: Jalisco, Colima and Michoacán, or the regional coverage made by Molina del Villar (1988) for the northwestern part of Mexico. Some previous efforts were the works of González-Ramírez (1981) on Puebla, superficially covering the 1575-1980 period, and Núñez-Cornú and Ponce (n.d.) on Oaxaca, which covers only the 19th century with a selection of the strongest Oaxacan earthquakes. Many of these compilations and catalogues have used the same methodology as «Earthquakes in Mexican History». Undoubtedly, these local, state and regional efforts will improve the existing databases, which will lead to a new national catalogue with local, state and regional addenda to «Earthquakes in Mexican History».

What have these compilations on historical earthquakes in Mexico inspired? What type of work was produced after them? How do seismologists use this qualitative information carefully collected and systematized by historians?

Table I. 19th Century nation-wide Earthquake Compilations.

\begin{tabular}{clc}
\hline \hline Edition date & \multicolumn{1}{c}{ Author and title } & Coverage \\
\hline 1837 & C.M. Bustamante «Temblores de México...» & $1620-1835$ \\
1861 & J.G. Romero «Noticia de los terremotos...» & $1532-1861$ \\
1864 & J.N. Adorno «Memoria acerca de los terremotos de México» & $1532-1864$ \\
1887 & J. Orozco y Berra «Efemérides seísmicas mexicanas» & $1460-1887$ \\
1890 & M. Martínez Gracida «Catálogo de terremotos...» & $1507-1885$ \\
$(\mathrm{~ms})$. & E.R. de Zayas «Los Estados Unidos Mexicanos...» & $1460-1884$ \\
1893 & &
\end{tabular}


What have seismologists done since the edition of «Earthquakes in Mexican History» and other derived catalogues? According to the National University (UNAM) and the National Polytechnic Institute (IPN), seismologists are still generating instrumental catalogues going back only as far as 1900, the instrumental period of Mexican seismology (Zúñiga, et al., 2000). The seismic instrumental catalogues for the Mexican Republic have been used, for example, to divide the country into four seismic zones (fig. 4), in order to design anti-seismic strategies. This type of catalogues should include homogeneous historical intensities and other parameters useful for hazard and risk studies.

Although there has not been a sequel to «Earthquakes in Mexican History» for the period after 1912, seismologists interested in this subject acknowledge that this work has allowed them to study specific historical earthquakes. Nevertheless, even today some seismologists express uncertainty in the use of past earthquake records. They accept that it is very im- portant to have such records, but they regret that some data are not always accurate and reliable. Sometimes the information is diffuse and it is not easy or feasible to estimate the magnitude, assign the intensity, locate the epicentre. What has been done with instrumental records has been very useful to understand pre-instrumental ones. It is important to know, for example in Mexico City, how large and how frequent the earthquakes are, where they have done most damage, how intense the movements are, and make comparisons between past and present records. But for a seismologist it is crucial to identify the epicentre, and it is not always easy to find out where it was.

Isoseismal maps have been made with preinstrumental records, based mainly on 19th century records, but the weakness of qualitative data for some purposes persists. Looking after information coming from more local sources may help to avoid these gaps. Nevertheless past earthquakes records have led to major advances in seismology, as well as in so-

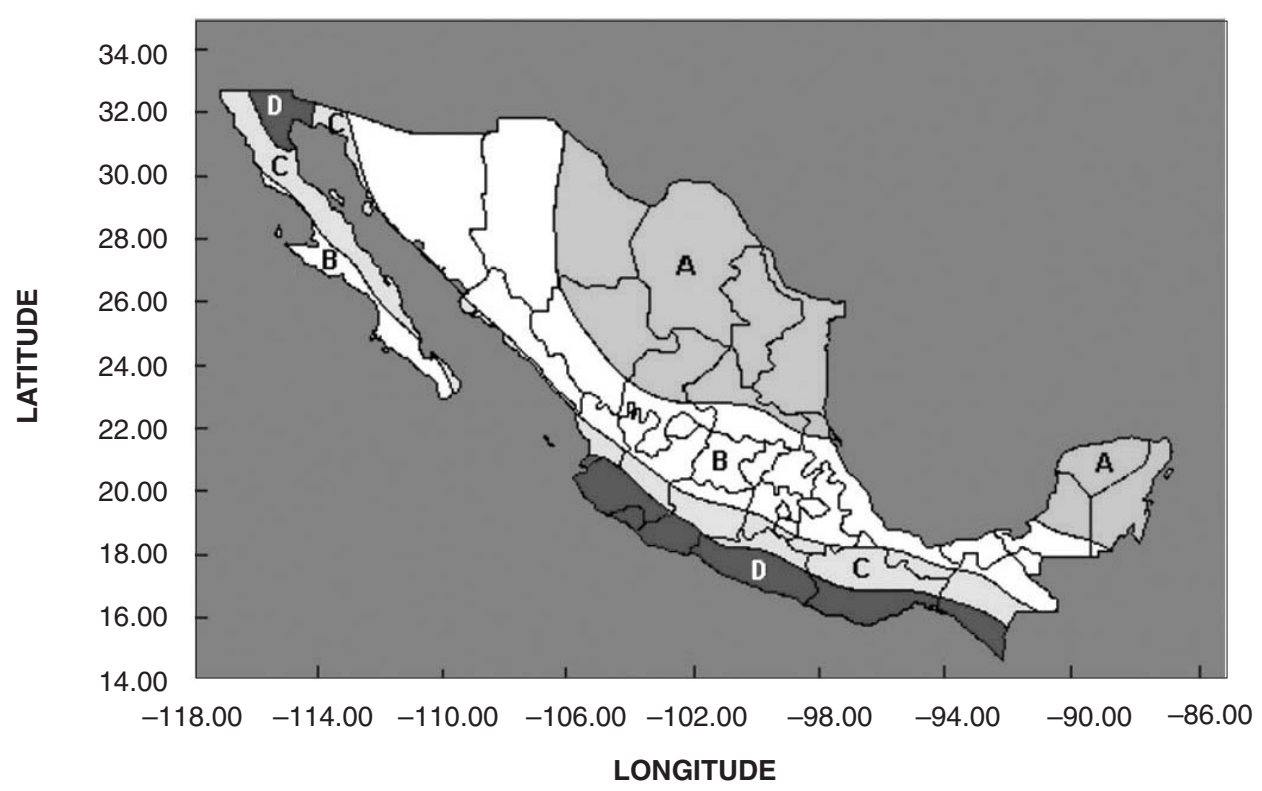

Fig. 4. Mexican seismic zones: $\mathrm{A}=$ no historical earthquake records for the last 80 years; $\mathrm{B}$ and $\mathrm{C}=$ intermediate zones; D = large historical earthquakes recorded (courtesy of Servicio Sismologico Nacional, Instituto de Geofisica, UNAM, Mexico). 
cial sciences, or in multidisciplinary products (Suárez et al., 1994). By using historical catalogues, several seismologists have carried out case studies on certain earthquakes and with very concrete objectives, such as the work by the Centro de Geociencias (Earth Sciences Center) at UNAM. This Center has studied mainly tectonics and its effects on Central Mexico in states such as Aguascalientes, Guanajuato and Zacatecas, in contrast to the enormous amount of research developed for the coastal or subduction zone. Another example comes from the research done also with information coming from «Earthquakes in Mexican History» on the 1887 earthquake that hit the north-western Sonoran area with intensity of 8 to 9 , which seems to exemplify what is known in seismology as «triggering». An effort including these type of analyses will be achieved with the future publication of the third volume of «Earthquakes in Mexican History». If volume one of this series includes the seismological compilation and volume two the analysis social scientists made with that information, forthcoming volume three will offer the seismological perspective emerging out from the same information included in volume one.

The construction of historical catalogues with earthquake records constitutes an effort that has been made all over the world since several centuries. Current state-of-the-art of similar studies in Latin American countries during the last 50 years look very encouraging. Past earthquakes have been recorded employing several methodologies and sources, but they are not so different from one another.

These ideas lead us to some unanswered questions we already posed ourselves at the beginning of this workshop. Some of these questions are the following: How should historical earthquake catalogues be made? Should they be all-inclusive with the information coming from every event ever reported? Should fakes be excluded or not? Which is the best methodology for a really complete catalogue? How to deal with these specific historical sources? How can different sources be treated? Can a World Catalogue be built? How? Is it feasible?

We still have many questions, but we should agree on at least one thing. The starting point that encourages this search is the same that has inspired the construction of catalogues with information coming from the past, and this starting point is based on the idea that historical records should help protect from earthquakes.

\section{Acknowledgements}

I wish to thank Shri Krishna Singh (UNAM), Ramón Zúñiga (UNAM) and Fernando Angulo Brown (IPN) for the information they offered on current uses of qualitative data for seismological purposes.

\section{REFERENCES}

AdORno, J.N. (1864): Memoria acerca de los terremotos en México escrita en octubre de 1864 por ... (Imprenta de Mariano Villanueva, Mexico).

AMERLINCK, M.C. (1986): Relación histórica de movimientos sísmicos en la Ciudad de México (1300-1900) (Socicultur, Mexico).

Bustamante, C.M. (1837): Temblors de México y justas causas por que se hacen rogaciones públicas (Imprenta de Luis Abadiano y Valdés, Mexico).

Escobar, A. (2003): Desastres agrícolas en México. Catálogo histórico (CIESAS, Fondo de Cultura Económica, Mexico), vol. 2 (in press).

FuENTES, S. (1987): Estudio del glifo 'temblor de tierra', in $Y$ volvió a temblar.. Cronología de los sismos en México. De 1 pedernal a 1821, coordinated by T. ROJASRABIEla, J.M. PÉrez-ZeVallos and V. García-ACosta (CIESAS, Mexico), 173-196.

García-Acosta, V. (2001): Los sismos en la historia de México (Fondo de Cultura Económica, CIESAS, UNAM, Mexico), vol. 2.

García-Acosta, V., R. Hernández, I. Márquez, A. MoliNA, J. M. PÉREZ, T. RoJAs and C. SACRISTÁN (1988): Cronología de los sismos en la cuenca del Valle de México, in Estudios sobre sismicidad en el Valle de México (DDF, PNUD, Mexico), pp. 409-498.

García-Acosta, V. and G. SuÁrez-Reynoso (1996): Los Sismos en la Historia de México, (Universidad Nacional Autónoma de México, Centro de Investigaciones y Estudios Superiores en Antropologia Social, Fondo de Cultura Económica, Mexico), vol. 1, pp. 718.

García-Acosta, V., J.M. Pérez-Zevallos and A. Molina DEL Villar (2003): Desastres agrícolas en México. Catálogo Histórico (CIESAS, Fondo de Cultura Económica, Mexico), vol. 1 (in press).

Garduño, V.H., A. Cuevas MuñIZ and R.J. Escamilla TORRES (1998): Descripción Histórica de la Sismicidad en Colima, Jalisco y Michoacán (Universidad Michoacana, Universidad de Colima, Morelia, Mexico).

GazZini, M., P. Margaroli and M. P. Zanoboni (1991): Fonti 
per lo studio di terremoti in area padana nei secoli XI-XV, in Atti del Convegno GNDT, edited by P. ALBINI and M.S. BARBANO, Macrosismica, Bologna, vol. 2, 37-45.

GonZÁLEZ-PoLO, I. (1985): Temblores y terremotos en la ciudad de México. Siglo XVIII, Boletín de la Sociedad Mexicana de Geografía y Estadística, CXXXVI, I, 31-47.

GonZÁleZ-RAmíREZ, Z. (1981): Historia sísmica del estado de Puebla, BA Thesis Geography, (UNAM, Mexico).

Luna BAuZA, C. (1992): Sismos en el estado de Veracruz (Gobierno del Estado de Veracruz-Llave, Mexico).

Manzanilla, L. (1985): Relación de los sismos ocurridos en la ciudad de México y sus efectos, Revista Mexicana de Sociología, 48 (2), 265-282.

Martínez Gracida, M. (1890): Catálogo de terremotos desde 1507 hasta 1885, in Cuadro Sinóptico, Geográfico y Estadístico de Oaxaca, ms.

Molina del ViLlaR, A. (1988): Cronología de sismos en el noroeste de México, siglos XVIII y XIX, in Memoria del XV Congreso de Historia y Antropología de Sono$\mathrm{ra}$ (Instituto de Investigaciones Históricas, Universidad de Sonora, Hermosillo), I, 253-272.

Musson, R.M.W. (1986): The use of newspaper data in historical earthquake studies, Disasters, 10 (3), 217-223.

NúÑEZ-CORnu, F. and L. PONCE (n.d.): Zonas sísmicas de Oaxaca, México: Sismos Máximos y Tiempos de Recurrencia para el Periodo 1542-1988, ms.

Orozco Y BerRA, J. (1887-1888): Efemérides seísmicas mexicanas, Memorias de la Sociedad Científica «Antonio Alzate», I, 303-541.
RodRíGuEZ-LAPUENTE, M. (1995): Foreword, in Miracles on the Border. Retablos of Mexican Migrants to the United States, edited by J. DuRAND and D. S Massey (The University of Arizona Press, Tucson), pp. XI-XII.

Rojas-Rabiela, T., J.M. PÉReZ-Zevallos and V. GarCíaAcosta (Editors) (1987): Y volvió a temblar.. Cronología de los sismos en México. De 1 pedernal a 1821 (CIESAS, Mexico).

Romero, J.G. (1861): Noticia de los terremotos que se han sentido en la República Mexicana, desde la conquista hasta nuestros días, Boletín de la Sociedad Mexicana de Geografía y Estadística, VIII, 468-470.

SSN Servicio Sismológico Nacional (on line: http://www. ssn.unam.mx).

SuÁreZ, G., V. García-Acosta and R. Gaulon (1994): Active crustal deformation in the Jalisco block, Mexico: evidence for a great historical earthquake in the 16th Century, Tectonophysics, 234, 117-127.

VizCAÍno, J.S. (1986): Crónicas de Zapotlán. Historia de los temblores, 1543-1985 (Archivo Municipal, Zapotlán, Mexico).

ZaYAS, E.R. (1893): Los Estados Unidos Mexicanos, sus condiciones naturales (Oficina Tipográfica de la Secretaría de Fomento, Mexico).

ZúÑIGA, F.R., C.M. VALdÉS-GonZÁLEZ and M.A. REYES (2000): A general overview of the catalog of recent seismicity compiled by the Mexican Seismological Survey, Geofísica Internacional, 39, 161-170. 